\title{
SLAVKO ZLATIĆ: A COMPOSER BETWEEN INTEGRATION TEACHING DAYS AND INCLUSION
}

\author{
Marija Crnčić-Brajković, BA \\ Juraj Dobrila University of Pula (Croatia) \\ Department of Educational Sciences \\ e-mail: crncicbrajkovic@yahoo.it \\ Rosanna Biasiol Babić, BA \\ “Giuseppina Martinuzzi” elementary school, Pula (Croatia)
}

\begin{abstract}
S u m m ary
Students of the Department of Educational Sciences at the Juraj Dobrila University of Pula, within the framework of Special pedagogy and Music culture seminars, have implemented an interesting long-term project. Their objective was to bring into classrooms and various other institutions those known figures and their music that have characterized and still characterize our region.

In this academic year they have decided to pay homage to one of the greatest Istrian composers, Slavko Zlatić, by presenting his work before an unusual audience: children. Joint efforts invested by students and pupils of the first three classes of the elementary school "Giuseppina Martinuzzi" from Pula, as well as those from the Škola za odgoj i obrazovanje (Education and Training Center) also from Pula resulted in an entirely different proposal in the field of music education. The program proposal is based on the new model of educational planning, Croatian National Education Standard (HNOS), that encourages valorisation of resources offered by the territory and giving an opportunity to all who are willing to contribute towards social integration, development of self-expression and human growth.
\end{abstract}

Key words: socialization, communication, inclusion, integration teching days, inclusion, activities, objectives, the composer, elements of Istrian music

\section{Music activities as a key to other fields of knowledge}

For human beings music is a necessity, given that it is an integral part of our general culture. This means that music is inextricably linked with the personalityforming process; it represents a universal language and stimulates creativity.

Teaching Music culture to children at elementary school is aimed at developing pupils' sensitivity to music and music activities. Through rhythm, melody, harmony, 
musical compositions and the use of special instruments, music conveys messages and plays a leading role in the growth process of a child. The initiation to the world of sounds becomes an important moment in the course of learning and development so much that musical experiences can reflect in a positive way on pupils' success in all other fields of knowledge.

The past decade was marked by the reform of the elementary school education system, which includes programs based on new proposals in educational planning (HNOS). This reform has also led to reorganization of music culture lessons, by drafting new didactic proposals and fixing highly structured objectives.

Music culture lessons that include listening to music, singing and playing an instrument are not only bound to improve pupils' musical abilities, but also to involve and enhance their cognitive abilities as well as their emotional state. The idea is to create optimum conditions for free expression of individual and group creativity, thus avoiding possible conditions of stress and anxiety which are often present during stereotyped lessons.

What is more, in its therapeutic role, music can be an important means of communication during all the activities and in every rehabilitation phase, especially when it comes to children with development difficulties. Music naturally brings joy to children by making them feel stronger and merrier. It enhances children's learning abilities and enables their active participation. Through activities like listening or choral singing, children gain a stronger sense of community, cooperation and socialization.

By creating a relaxing atmosphere, music becomes an excellent integration tool used to facilitate establishing relations among people. "With the aid of music, individuals who have trouble articulating even a few words, learn to formulate complex concepts" (Cervellati, 1993).

Today more than ever, applied pedagogy recognizes the utmost importance of music in enabling every child:

- to participate actively in the activities

- to acquire a good level of socialization, acceptance and autonomy

- to become aware of their personal competence and their objective importance within the community (Feuser, 1989).

Children with development problems often see music as source of enthusiasm, gratification and satisfaction. Through music they discover the world, explore sounds and their sources and learn to play with melody and rhythm. Various educational sensory experiences, such as exploring auditory perception of sound experiences and active listening to instrumental and vocal music, are utilized to activate music in any of its aspects: voice, body and rhythm. That is why listening is an inevitable phase in every child's learning process.

Musical excerpts proposed for listening must respect the phases of modern music didactics, involving the listeners' emotional state through perception, hearing and reflection, thus truly becoming what Massimo Calegato defines as ascolto partecipato ("active listening"), (Calegato, 2004). The purpose of teaching children how to listen to music is manifold: the children embark upon a journey into the world of auditory 
perception, sounds and music which becomes alive before their eyes, affecting them on a deeply emotional level.

The path towards understanding music begins with HEARING music (auditory perception), continues by LISTENING to it (which generates an emotional reaction) and culminates in UNDERSTANDING (being able to express and convey one's experience). All this is a necessary prerequisite for the next step which is playing music. In this way, listening is integrated with motorial, graphic, manual, dramatic and many other activities irrespective of child's abilities (Frustraci, Tagliarini, 2007).

There are many ways to listen to music. Listening can be (Barbieri, 2006):

- evocative - letting the music suggest emotions, mood, images and instruments)

- selective - identifying a specific element in music (characteristics of music

- active - engaging in various forms of activity related to listening:

dancing - helps the child learn how to follow the tempo, enables him/her to understand internal structure of the piece

$>$ singing - develops attention to individual notes according to their height and duration

> eurhythmics - helps the child understand that there is a constant rhythmic pulsation

movement - introduces the child to the bodily dimension and coordination of movement

use of images - enables the child to recognize the composition's form and model by placing it into its geographic and historic context

cognitive - acquiring musical knowledge such as learning music theory and its practical application.

General proposed objectives are:

* to introduce children to listening as an extremely important sensory activity

* to help children discover that the musical world is full of stimuli and that musical genres are many

* to make children understand that no musical piece is "hard" to listen and that listening is not a passive activity, but an active one, as well as selective, personal or collective and above all pleasant

to offer equal opportunities to all children.

This was the approach used in planning the above mentioned didactic activities. 


\section{Musical journey into instrumental and choral works of Slavko Zlatić}

Music researchers, interpreters and theoreticians have already made Slavko Zlatić's work and contribution to the Istrian cultural heritage a subject of numerous conferences and colloquiums. His life and works can easily be expressed as a series of episodes on both historic and human level, woven together as threads of one fabric in a highly creative fashion. Zlatić is perceived as a unique artist distinguished by his originality, refinement and musical style. Indeed, for him the sheer inventiveness of the act of composing was always to be found in unique rhythm and sound of the traditional music.

In fact, paying homage to Slavko Zlatić as one of the most notable and shining custodians of the Istrian musical heritage was one of the main objectives of the initiative promoted through cooperation between the Department of Educational Sciences of Juraj Dobrila University and the first three classes of the "Giuseppina Martinuzzi" elementary school from Pula as well as those from Pula Education and training centre (Škola za odgoj i obrazovanje).

Nevertheless, this project is only partially directed to the discovery of the personality of Slavko Zlatić, leaving out the structural, stylistic and historic analysis of maestro's work. The project is actually about presenting didactic strategies and processes as a path to present new content and new personalities to pupils. The idea is to introduce subjects that children know nothing about, but which have the potential for raising their consciousness and teaching them to appreciate music inspired by the local tradition.

It has been ascertained by now that modern education needs much more than the traditional didactic methods. Teaching and learning become different, richer and more incisive with the introduction of new forms. When teachers decide to combine diverse methods and means at their disposal and to involve other disciplines, children become more enthusiastic about learning. The term for this is interdisciplinarity and it should be regularly applied as one of the best educational innovations, as seen in the occasion of integration teaching days. Such symbiosis always brings excellent results in the field of learning. Learning becomes easier and faster in quantity and quality, and, above all, it enables children to increase the totality of their cultural, social and emotional competencies.

The new activities proposed within the subject of Music culture offer a greater freedom to the teacher in the choice of themes and subjects when planning their lessons. They also represent a marvellous opportunity to organize stimulating courses by drawing inspiration from the region.

Organizing integration teaching days within the Music culture seminar in the first three classes of elementary school was only one aspect of the opportunities offered by this project. The other aspect was performing choral compositions in front of an audience of children with development difficulties, which made the subject very pleasant and surprisingly engaging to them. 
By including the pupils with difficulties in the development in this project we wanted to explain to the students that inclusion is meant as an essential way to enter the cultural and psychological dimension of the acceptance, so to develop those dynamical relations necessary for further future activities. By introducing in the scholastic world of the children with difficulties the music of Zlatic and including this pupils in the celebration of his anniversary, new perspectives and opportunities have been created for greater and real inclusions.

The students' idea was to present a portrait of the great Slavko Zlatić and to "use him" for didactic and pedagogical purposes, which added an educational dimension to their initiative. During their lessons, in the light of celebrating the hundredth anniversary of maestro's birth, the pupils learned about his life and experiences which shaped his studies and played a major part in his later success and accolades.

The compositions "Pazinska zvona", "Ples iz Istre", "Balun" were not randomly selected and their assignment to respective classes was well planned. On one hand, it was important that the pupils can make connections between these works and other subjects, and on the other hand they had to be in line with the rest of the Music culture programme. This resulted in a very successful integration of all curricular activities. The objective was to offer a possibility of a different kind of amusing encounter with the world of sounds, lived as a stimulating and engaging experience.

Even the selection of compositions for a white voice choir Sedela tužna grlica, Pleši, pleši črni kos, Za ples was based on the unique audience profile. Its purpose was to engage the children on an emotional level through melodious and joyful singing. Compositions for children occupy an important place in the opus of Slavko Zlatić. In fact, since his tender age, the composer showed a particular musical creativity in creating works for white voice choirs. In this segment as well, the maestro has drawn his creative resource from the rich popular music, tradition and folklore.

The Listening activities (instrumental and vocal music) were actually the basis for a new course, the purpose of which was to introduce pupils to an array of expressive forms of the Istrian folklore, which proved to be the source of high educational potential.

\section{“Giuseppina Martinuzzi” elementary school, Pula}

\section{First grade}

Pazinska zvona was the composition selected for didactic elaboration in the first grade. It is a composition for symphonic orchestra including a magnetic tape recording. The creative aspect of incorporating the actual sound of Pazin bells in the sound ambiance of the orchestra aroused an honest interest in young listeners. Specific objectives were focused on learning dynamic progressions present in the composition, recognizing the tone of instruments and character of the music.

The pupils were encouraged to follow attentively not only the changes in intensity created by the crescendo process, but also to notice the gradual rise in dynamic 
conditioned by progressive unification of the entire instrumental ensemble, the way to get the most out of the sound possibilities and to create unique situations in relations among different orchestral tones. The musical intensity is perceived by the listener as an interesting flow of elements that gradually blend right up to the culmination with the participation of strings, woodwinds, brass and percussions. The contrasts born from an ample and colourful harmonic and rhythmic sphere give a certain vitality to the composition, always rich with new events, interesting and sometimes even dramatic harmonic formations, alternated with short intervals of calm, thus maintaining listeners' motivation on a high level.

\section{Second grade}

Quintet for woodwinds, entitled Ples iz Istre, composed by Slavko Zlatić in 1936, was chosen for the lesson of Music culture with second grade pupils. The subject matter was the dialogue between musical instruments: flute, oboe, clarinet, bassoon and horn. In this chamber music composition, the musical language becomes an artistic and educational phenomenon. Its extraordinary musical delicacy and lightness at times gives an impression of soloist performances. During the lesson, the pupils were introduced to the unique sound of each instrument, so that all pupils had the opportunity to learn about interpretation qualities and about the reasons for which they were selected with great care, which was decided by the author and conditioned by the dancing character of the music.

These characteristics, conveyed to the listener through rhythm and melody, were a basic element for the development of an active dialogue between the pupils and the teacher. This chamber music piece is only partially linked to the dancing character of the popular music because the Quintet contains the author's original melodies partly inspired by the Istrian musical tradition.

The interest for instrumental music enables the author's unique approach and creativity through the melodic and rhythmic expression with the use of winds. Musical freshness combined with moments of light-heartedness in Allegretto con movimento, derives from rhythmic figures present, as well as from metric changes which accentuate the dancing character of music, an expression close to the pupils' character.

\section{Third grade}

The use of winds has once more proved to be a good choice in case of the instrumental composition with a captivating title "Balun", composed in 1934. The chamber formation for oboe, bassoon, saxophone contralto alto (E flat) and English horn, was the subject matter chosen for the Music culture lesson with the third grade pupils. Even if it is basically inspired by a traditional Istrian dance and today is still a piece on the repertoire of many local folklore groups, the author's choice of winds indicates his desire to maintain the authenticity of sound, i.e. of the link with traditional instruments that accompany the dance in popular practice, sopele or roženice. Even if it is original author's music, it is still very close to musical peculiarities of the dance. In 
fact, aside from the careful choice of instrumental sounds, the composer preserves the same link to the dance even regarding the music tempo and structure of composition. It's obvious that the author's musical artistic creativity derives from melodic and rhythmic movements, harmonic structures which are very close to the musical tradition of Istria and Primorje-Gorski Kotar county contained in the typical time signature (2/4). Nevertheless the composition occupies an important place in the chamber music for wind instruments. Pupils have engaged in a very positive activity after listening to the piece: they started a long and rich discussion on the subject of Istrian musical tradition by asking subject-related questions.

\section{Interdisciplinary didactic activity}

Taking Music Education for a pillar around which other subjects were inserted, we started upon a journey which made it possible to introduce to the class, with the aid of the composer's music, the territory with thousands of its nuances, as well as the Istrian popular culture and folklore (See Conceptual maps 1a, 2, 3a).

Music has become a unifying and socializing factor for the pupils, as well as a moment in which they can dwell more deeply on their own culture and get to know it better, a bridge between school and territory. This is how school became an active partner in a programme for musical culture dissemination.

In the course of implementation of the didactic course, numerous didactic objectives were reached, and the most important ones among them are:

* Carrying out an innovative musical course within the frame work of planning the integration teaching days which would enable the pupils to follow interdisciplinary courses focused on deepening the knowledge about their region

* Encouraging the meeting between various musical forms and languages originating in our region.

* Promoting valorisation of the Istrian musical heritage understood as one of the human and material resources

* Developing the capacity to operate and reflect upon musical language by acquiring fundamental and precise terminology

* Promoting communication and exchange between various experiences taking place in the region.

* Favouring creativity and socialisation

* Encouraging and awakening pupils' interest

* Using music to build bridges of intercultural creativity, mutual acceptance and discovery

We hereby also present the distribution of spaces in which the activities took place, connections to the disciplines involved and the list of pieces included in the final production: 
Spaces: classrooms, school gym

\section{Connections}

- Languages: Italian, Croatian, English

language

- Analysis of linguistic structures which draw a parallel between music and

- Mathematics

- Art

- Physical Education and Health

- Class community

Production

- Posters, drawings, photographs

- Written and iconographic material

- Audio and video material of physical activities

- Media publicity

The 100th anniversary of the birth of Slavko Zlatić was an opportunity to create an actual "didactic playground". From this playground and through his music children were able to perceive the composer's love for Istria and its popular music, the main point of reference in his work. The privileged relationship of the composer with the region enabled him to venture into new dimensions of complex, refined and valuable creativity with a musical style that combines traditional tunes with contemporary sounds by engaging instruments in a spontaneous dialogue.

Zlatić's work offers an array of modalities relating to the folk music based on the Istrian musical scale: he studied it, revitalized it and used some of its elements just to keep the old musical tradition alive. For this reason, even the smallest children were fascinated by the most genuine expressions of his music, because they were offered an extraordinary experience in an artistically and culturally stimulating context.

\section{"Education and Training Center", Pula}

The School Day celebration was performed by the participation of students in the artistic and cultural programme by performing in front of the pupils some of the works composed by the maestro in 1974:

1. Sedela tužna grlica - song for a choir of two voices, sentimental and melancholy character, based on a folklore motif from Šumber area

2. Pleši, pleši črni kos - cheerful, playful and amusing song for two voices whose lyrics are based on a colourful traditional poem

3. Za ples - three voice interpretations of music and lyrics written by the author, a narrative song in moderate tempo 
The composer was always inspired by the popular tradition, rediscovering and utilizing not only the lyrics inspired by popular poetry but also his own original lyrics.

The songs performed have succeeded in conveying the enthusiasm of the performer to the pupils in such a way that they became a tool for integration with the capacity of enhancing their expression and communication.

Musical expression has thus enabled an efficient interaction among pupils, students and professors, which resulted in plans for future cooperation projects in the field of art and physical education and health. It can be one of many ways to make the disability progress towards a real inclusion.

Some of the general objectives have been seriously considered (Lascioli, Saccomani, 2009). These objectives particularly referred to future preschool and primary school teachers and to raising their awareness on the subject of rehabilitation resources and on modern pedagogy methods such as:

the fore

- interaction with children with disabilities, striving to bring their uniqueness to

- analysis of own resources (ordinary, additional, professional...) and combining them with the ones available in the working environment

- openness to all possible types of cooperation and their activation

- seeing all pedagogical projects as professional and human challenges

- total involvement of one's professional, intellectual and emotional capacities

- firm, constant and expressed belief in success of every single disabled child

On the emotional level children felt motivated by the music to actively participate in other similar activities.

The course has equally awoken a large interest among students who are willing to continue in this direction by organizing exercises that combine music with play and by further upgrading their competencies in the fields of diagnostics, therapy and rehabilitation.

At first I was a little worried. Once we arrived all my fears disappeared. The children accepted us without problems, applauded and at the end they sang with us. The atmosphere was really magic. It was worth preparing a small programme and showing it to the children who were really happy. It was such a beautiful experience that I would like to repeat.

The morning was very interesting. I noticed some children were very interested in the programme and us. The music was a moment of fun and happiness for them. All of them got involved a lot, they applauded and had fun. I think I can give a lot to these children. Today they gave a lot to me. 
Our choir had its first public exhibition. I had already known the school so I was not so much excited as I was the first time although it was nice to see the children and their teachers again. There was an uproarious applause. A real award for us was their smile. I realized that the people with different abilities could remind us the essential values of life showing pure joy and giving gratitude with no limits.

I am an enthusiast for the experience because it helped me to be useful and through music I made happy a lot of children. In return they gave us smiles. It is obvious they were happy. I hope I will have similar occasions in the future. I could enlarge my knowledge on different handicaps and I could help children to face major difficulties.

\section{Conclusion}

In conclusion, the success of the above mentioned activities proves that schools should open up to all initiatives that create symbiosis between cognitive and emotional dimension which in turn creates enthusiasm and involvement of all pupils. The musical excerpts proposed to the pupils succeeded in conveying the rich variety of autochthonous local expression. Such musical variety stems from close links to the territory, as well as from a vivacious exchange among manifold music identities present on the territory.

The excerpts taken from compositions of Slavko Zlatić, as well as their vocal presentations led to a beautiful experience of working together. Such experience was particularly valuable to the children as they discovered the magical force of music which brings people together and instils joy in everyone.

The students have also had immense benefit from this experience. By discovering and learning to accept different realities, they made significant steps ahead in their vocational training. The universal language of music was used as a tool for creating a synergy among everyone involved. As a result, barriers of prejudice disappeared and everyone opened up to the lively exchange among various realities and identities.

Only in this way, by becoming fully aware of our roots and others' needs, we can truly raise new generations of young people capable of embracing the idea of a civic society.

\section{Bibliography}

AAVV Istarska enciklopedija (2005) Leksikografski zavod Miroslav Krleža, Zagreb. 
AAVV Una introduzione all'Educazione speciale (2009), Raffaello Cortina Editore, Milano.

Barbieri, S. (2006), Proposte per un percorso di educazione all'ascolto musicale in Un anno a Belprato - Guida didattica, Edizioni Il capitello, Torino, Pag 11-21.

Cervellati, M. (1993), Handicap - la scuola di tutti, Temi spa, Bologna.

Feuser, G. (1989), Didattica differenziata: una possibilità per tutti i bambini, atti del Convegno Un integrazione possibile Comune di S. lazzaro di Savena (BO).

Celegato, M. (2004), Per una pedagogia dell ascolto partecipato, Atti del XXXV Convegno Europeo di studi sull'educazione musicale e sulla musica corale, Gorizia, p. 91-95

Frustaci, R. - Tartaglini, I. (2008), Educazione al suono e alla musica, Giunti scuola, p 17-44

Gortan-Carlin, I. P., Lovrinić N., Veljović, M. (2010), Slavko Zlatić - svestrani istarski glazbenik, in Jurina i Franina - istarski kalendar za 2010. godinu, Reprezent, Buzet.

Gržinić J., Rabak V., Borščak V. (2007), Uloga učitelja u kontekstu integracijske i korelacijske nastave, Zbornik radova, Deontologija učitelja, Pula, p.465

Pernić, R. (1998), Meštri svirci i kantaduri, istarski narodni pjevači, svirači i graditelji glazbala, Reprezent, Buzet, p 8-173

Tomašek A., Zlatić, S. (1985), Kronika života i rada, Narodno Sveučilište Poreč, Poreč

Vidulin-Orbanić, S. (2007), Poučavatelji u suvremenoj ulozi inicijatora i suradnika, Zbornik radova, Deontologija učitelja, Pula, p.343 


\section{CLASS Ia}

Teacher: Loredana Franjul; collaborator: Luka Brussich; student: Petra Fabris; professor: Marija Crnčić - Brajković

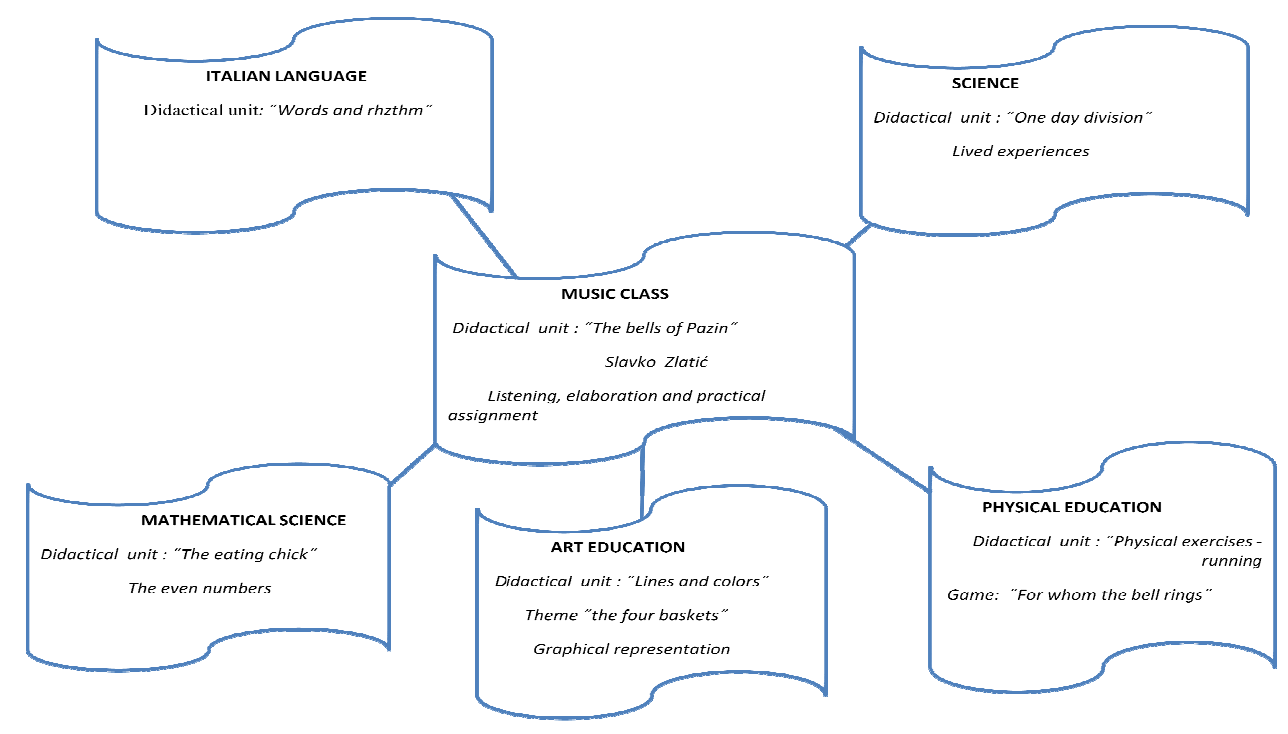




\section{Class II}

Teacher: Rosanna Biasiol. Babić; collaborators: teachers Sanja Močenić. Sandra Keserovič, Miriam Mendica; student: Ariana Moscarda; professor: Marija Crnčić Brajković

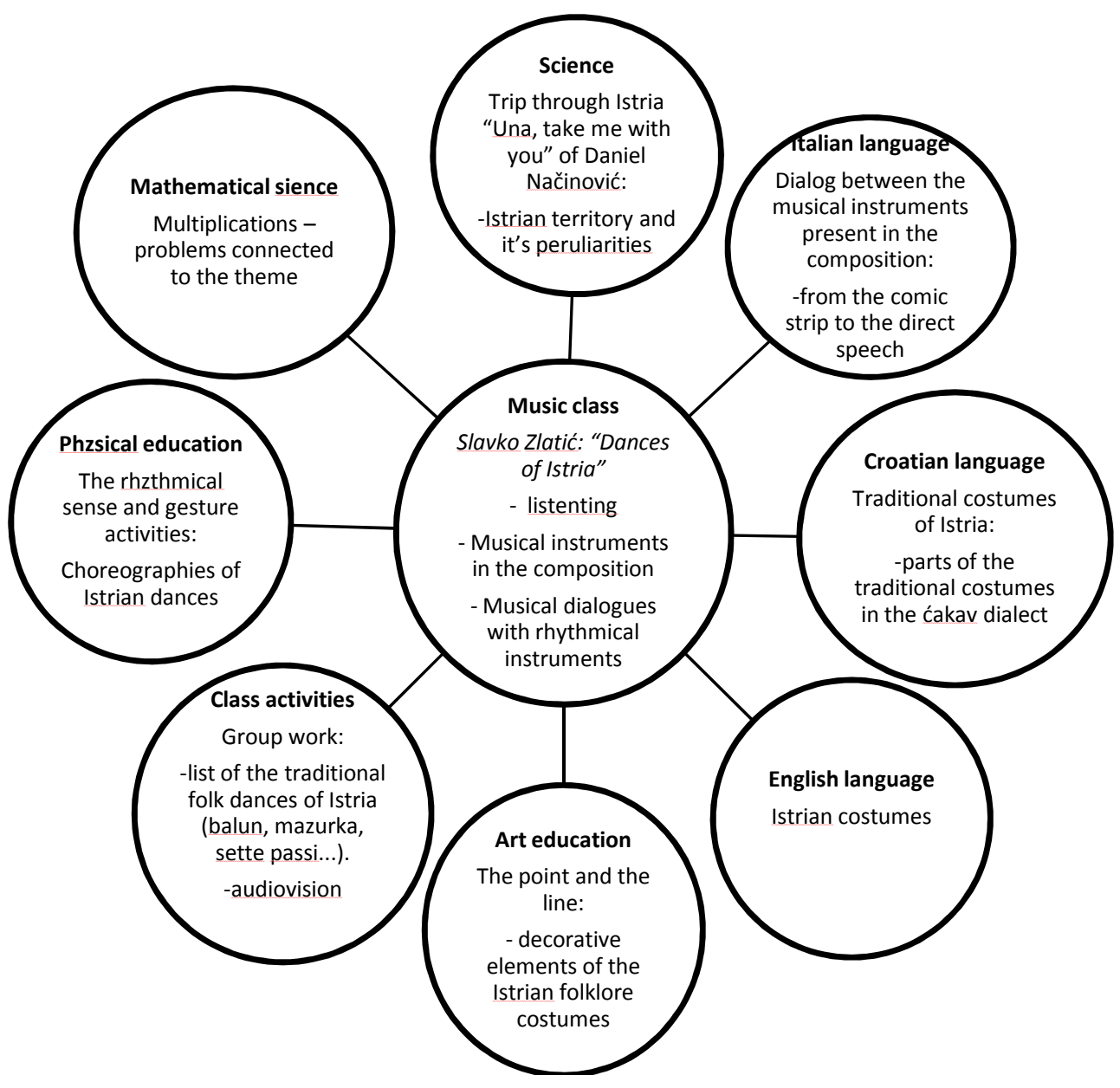




\section{CLASS IIIa}

Teacher: Ester Contossi; collaborators: teachers Sandra Keserović, Miriam Mendica; student: Branka Marušić; professor: Marija Crnčić Brajković

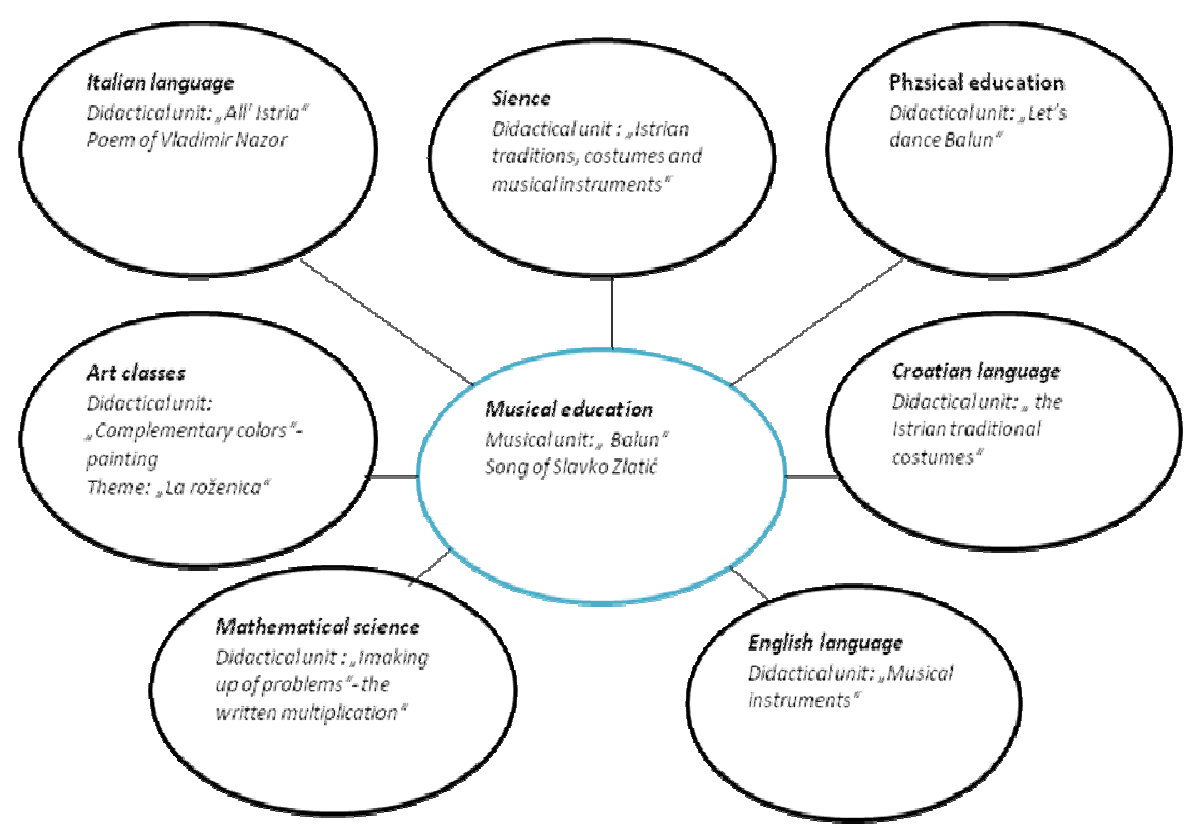


Metodički obzori 10, vol. 5(2010)2

Stručni članak

UDK: 378.678(497.5 Pula):78.071 Zlatić, S. Primljeno: 30. 5. 2010.

\title{
SKLADATELJ SLAVKO ZLATIĆ KROZ INTEGRATIVNE NASTAVNE DANE I INKLUZIJU
}

\author{
Marija Crnčić-Brajković, prof. \\ Odjel za odgojne i obrazovne znanosti \\ Sveučilišta Jurja Dobrile u Puli (Hrvatska) \\ e-mail: crncicbrajkovic@yahoo.it \\ Rosanna Biasiol Babić, prof. \\ Osnovna škola “Giuseppina Martinuzzi” u Puli (Hrvatska)
}

\section{Sa žetak}

Ovaj je rad produkt ideje koja objedinjuje sadržaje kolegija Specijalne pedagogije i Glazbene kulture, a za primarni je imala uvođenje novih, zanimljivih sadržaja vezanih uz glazbeno stvaralaštvo koje je kroz povijest obilježilo istarski poluotok, a i danas zadržava relevantan značaj kulturnih događanja vrijednih spomena.

U godini obilježavanja 100. obljetnice rođenja istaknutog istarskog skladatelja Slavka Zlatića poput izazova se nametnula zamisao o približavanju njegove glazbe koliko studentima toliko i mlađem uzrastu učenika osnovne škole.

Zlatić koji je kroz svoju kako vokalnu tako i instrumentalnu glazbu tonovima i riječima opisivao vrednote zavičaja, živopisnog krajobraza i vrlina njenog naroda, rezultirala su pravim izborom i pobudila veliki interes najmlađih.

Suradnja studenata i učenika od prvog do trećeg razreda osnovne škole „Giuseppine Martinuzzi“ u Puli s nastavom na talijanskom jeziku i učenika Škole za odgoj i obrazovanje u Puli doprinijela je upotpunjavanju i oblikovanju novih ponuđenih sadržaja u program Glazbene kulture.

Ovaj je projekt imao za cilj ponuditi svakom učeniku otkrivanje nepresušnog svijeta glazbe, onoga autohtonih vrednota i autentičnih radova koji izražavaju iskonsku povezanost sa zavičajem.

U uvjerenju da samo susret koji se dogodi posredstvom ljudskosti i sreće može iznjedriti već od najranije dječje dobi iskrenu emotivnu zaokupljenost ucrtalo je put metodičkoj pripremi temeljenoj na interdisciplinarnosti s ciljem usvajanja novih sadržaja pomoću organiziranih aktivnosti međusobno povezanima kroz slušanje glazbe, igru, pokret, socijalizaciju i druge kreativne sadržaje.

Izabrani didaktički pristup ostvaren je organizacijom integrativnih dana nastave, zorno prikazan i obrazložen u prilogu pomoću konceptualnih mapa iz kojih se dade zaključiti da je tematska okosnica nastavnoga dana bio sat glazbene kulture oko kojeg se razvio cijeli niz zanimljivih sadržaja ostalih nastavnih cjelina.

Tijekom nastavnog sata glazbene kulture s učenicima od prvog do trećeg razreda osnovne škole „Giuseppine Martinuzzi“ obrađene su instrumentalne skladbe Pazinska zvona u prvom, Ples iz Istre u drugom i Balun u trećem, dok su u Školi za odgoj i obrazovanje predstavljene vokalne skladbe za dječji zbor Sedela tužna grlica, Pleši, pleši črni kos i Za ples. 
Izbor tema je u skladu s novim načinom planiranja nastavih sadržaja prema HNOS-u, kojim se podupire vrednovanje zavičajnih osobitosti, otvara mogućnost socijalne integracije pojedinca i grupe, stjecanja novih spoznaja, razvoj sposobnosti izražavanja, humanog odrastanja i tolerancije.

Uspješnost realizacije navedenih aktivnosti pokazuje da suvremena škola mora biti otvorena za svaku inicijativu koja stvara simbiozu između misaonog i emocionalnog trenutka koji pospješuju entuzijazam i sudjelovanje svih učenika. Prilika je to i za same studente za profesionalnim usavršavanjem upućenim otkrivanju i prihvaćanju drugačijih realnosti. Stvoreno je jedinstvo kojim je omogućena komunikacija kroz univerzalnost glazbenog izražavanja do otvaranja bez ikakvih predrasuda živahnoj i dinamičnoj realnosti i različitosti.

Samo se na taj način kroz vedro saznanje osobnih korijena i postojanja drugih kod mlađih generacija doprinosi formiranju umova otvorenih civiliziranom društvu.

Ključne riječi: Socijalizacija, komunikacija, integrirani dani, inkluzija, aktivnosti, ciljevi, kompozitor, elementi istarske glazbe 